\title{
Normalizing democracy and human rights: discipline, resistance and carceralization in Croatia's Euro-Atlantic integration
}

\author{
Laura Zanotti \\ Department of Political Science, Virginia Polytechnic Institute and State University, 503 Major \\ Williams Hall, Blacksburg VA 24061, USA. \\ E-mail: Lzanotti@vt.edu
}

This paper explores the mechanisms of governance put in place by international organizations in the process of the pacification and Europeanization of Croatia, and the local administrations' strategies of resistance. In Croatia, international organizations enacted processes of subjectification organized around idioms of democracy and human rights, and deployed disciplinary and governmental methods for monitoring, transforming and steering the state's behaviour. These practices also inscribed spaces of resistance that have been used by different local governmental constituencies to accommodate, contest or hijack international agendas. This paper provides insights on how international regimes of practices in the post- Cold War era operate through isomorphic but decentralized normalizing processes. In doing so, it traces out the interaction between these regimes and local actors. Relying on governmentality theories, this paper also provides empirical support for conceptualizations of power as the structure of human interactions, and of resistance as strategic transformative action. Critiques of governmentality, inspired by Agamben, conceptualized power as domination, and resistance as total rejection of its inscriptions. The case of Croatia shows that international normalizing regimes of practices do not produce totalizing effects of domination, but regimes of carceralization that are always met with resistance. International regimes elicit the proliferation and intensification of mechanisms for monitoring, assessing and steering behaviour. However, the effect of these regimes is not the obliteration of political life. Instead, normalization opens spaces for continuously renovated modalities of resistance. Finally, this paper questions romanticized representations of 'resistance' as a path to 'liberation'. The political effects of power and resistance are ambiguous, and need to be explored in their contingent interactions.

Journal of International Relations and Development (2008) 11, 222-250. doi:10.1057/jird.2008.13

Keywords: discipline; European Union; governmentality; normalization; peacekeeping; resistance

Journal of International Relations and Development, 2008, 11, (222-250)

(C) 2008 Palgrave Macmillan Ltd 1408-6980/08

www.palgrave-journals.com/jird 
Nothing is bad, but everything is dangerous [...] If everything is dangerous, then we always have something to do (Michel Foucault).

\section{Governmentality, Normalization and Resistance}

In this paper, I use Michel Foucault's concept of governmentality to explore regimes of practices deployed in the process of the pacification and Europeanization of Croatia. The peace agreements brokered by the United Nations, the monitoring mechanisms set in place by the international community in order to protect minority rights, and the political and economic assistance provided to, and the conditionality imposed on, Croatia by the European Union (EU) and NATO testify to the deployment of multifarious, diffused, but decentralized disciplinary and governmental mechanisms. These were organized around liberal idioms of democracy, human rights, market economy and administrative effectiveness.

In recent years, studies that apply Foucauldian analyses of government (Foucault 1991a,b; Dean 1999; Rose 1999; Moran 2003) to the study of international dynamics have proliferated (Maurer and Perry 2003; Huysmans 2004; Larner and Walters 2004a, b; Lipshutz and Rowe 2005; Walters and De Haar 2005; Merlingen and Ostrauskauite 2006). Governmentality theories have been recognized as a distinctive theoretical approach to the study of international relations (Merlingen 2006). This body of literature focuses on the analysis of regimes of practices, that is, the how of power, its idioms, its technologies, its multiple and contingent configurations, local interaction and effects. For Foucault (1991b: 75), 'to analyze a "regimes of practices" means to analyze programmes of conduct which have both prescriptive effects regarding what is to be done and codifying effects regarding what is to be known'. Relevant questions in this regard are how specific idioms and rationalities have come to existence, how they are translated into practices of government, what forms of subjectification emerge, what spaces of resistance are opened, how these openings are strategically used by different actors and what political effects are produced in the process. Inquiries do not regard the legitimacy of power, but the modalities of its continuous transformation.

This paper maps the idioms and governmental mechanisms deployed by international organizations for maintaining order in Croatia. Through this case I show that in the post-Cold War, international security regimes of practices operate through the proliferation and intensification of mechanisms for monitoring, steering and disciplining potentially disorderly states. International power is not deployed as the projection (real or simulated) of the power of the Leviathan. ${ }^{1}$ In the face of the proliferation of threats, international organizations attempt to tame risk by transforming states perceived as disorderly into normal and responsible actors. Owing to the impossibility of controlling all variables, the security of liberal states depends internally upon the exercise of liberty by 
normalized subjects (Dean 1999: 116-17). Internationally, security is seen as the result of the 'responsible behaviour' of liberal democracies.

Practices of government involve the production of truths with regard to what is governed. Language is not secondary to government; it is constitutive of it (Rose 1999: 28). Starting in the 1990s, idioms of democracy converged with idioms of security. Normality is identified with liberal democracy and various degrees of international threats with non-democratic regimes. Bringing about democracy, market economy and human rights are seen as instruments for the pacification of disorderly states in the context of UN peacekeeping operations, as well as criteria for inclusion in international political associations and military alliances. Idioms of democracy, market economy and human rights subjectify states that lack these qualities as abnormal and make them the referents for practices of disciplinarization. The figure of the abnormal in the classical era was connected to the 'social monster': he who deviated from normal behaviour, appearance or who stood outside the law. The emergence of the social figure of the abnormal was matched by an intensification of emphasis on norms. Norms provide the benchmark for individual transformation and the basis for knowing and steering populations (Foucault 1975-1976: 353). Because they make it possible to measure gaps, norms homogenize and individualize. They elicit ranking and classification, inclusion and exclusion. Degrees of normality permit 'membership in a homogeneous social body but also ... [play] a part in classification, hierarchization, and the distribution of rank' (Foucault 19751976: 184). The transformation from abnormality into normality and from deviancy to responsibility is at the same time an individualizing and a standardizing process, where one's performance is compared with others' and assessed according to benchmarks that are the same for all.

International and supra-national organizations normalize deviant states through modalities that are isomorphic to the techniques invented in the classical era to normalize individuals and populations. The point of application of these techniques shifts from deviant individuals to the institutions of disorderly states. Disciplines are the techniques through which abnormal states are to be corrected and brought to behave normally, and as a result, safely. ${ }^{2}$ Disciplinarity, for Foucault, is a modality of exertion of power that relies upon technologies of individual transformation and domestication. Discipline builds responsible and productive members of society through capillary surveillance, mechanisms of reward/punishment, procedural codification, record keeping, training, tutorship and examination. Its goal is not to punish the body, but to actively correct the soul. Emerging contextually with the formation of administrative states in Classical Europe, disciplinarity overlapped with sovereignty as a technique of government. Not simply a manifestation of repressive power, discipline is 'productive' of modern subjects and requires the active engagement of those to be disciplined in the processes 
that are aimed at bringing about their normalization. Military academies, schools and correctional institutions are examples of disciplinary machineries where the subject is continuously engaged through counseling, training, and reward and punishment mechanisms. Progress and results are assessed through surveillance, virtual or real. In the post-Cold War era, deviant states are increasingly the target of international practices aimed at making them democratic, responsible towards their citizens, respectful of human rights and able to sustain the health and wealth of their populations through market economies. These include prescription of administrative procedures, advice on an array of legal matters, scrutiny and assessment of results, financial assistance, inclusion/exclusion mechanisms, and fostering knowledge to make governmental procedures and populations visible and transparent to international agencies. 'Government by community' (Rose 1999) has become a key tool of international normalization. In the last decades of the 20th century, inclusion into or exclusion from particular communities and the conditionality attached to public assistance became a means for normalizing abnormal individuals and transforming them into functioning elements of society. Thus, in order to be admitted into the community of citizens and receive the full benefits that derive from this status, 'abject' individuals must undergo moral reformation and behave responsibly and rationally (Rose 1999). Similarly, full admission of states into the 'international community' is linked to 'responsible behaviour'. Like full citizenship, in the context of normalizing regimes of practices, the exercise of full sovereignty is conditional upon behaviour and continuously scrutinized. ${ }^{3}$

The internationally sponsored peace agreements and activities of various international agencies in Croatia illustrate the migration to the international arena of governmental techniques that were previously adopted within states. For Foucault, the disciplinarization of punishment institutions produces a particular type of population: the 'delinquent'. Delinquency is a form of subjectification connected with the practices and expertise that emerged contextually with the invention of the prison and the shift of modalities of punishment from haphazard violence to disciplinarization. The delinquent is the subject of multifarious dispositifs of surveillance and techniques of correction of the soul deployed in the context of the carceral system (Foucault 1995). Carceral institutions produce the intensification of the techniques aimed at the delinquent's normalization, but are never successful in obliterating resistance. While power relations are uneven, complete domination or slavery - that is 'when the determining factor saturates the whole' (Foucault 1982: 221) - is not the normal outcome of relations of power. Freedom does not disappear in the process. On the contrary, it is a precondition for power to be exerted (Foucault 1982: 221). For Foucault, carceralization not only describes the modality of the prison, but also can be read as a more general way of ruling societies based on surveillance, knowledge and discipline. The case of Croatia 
explored here shows that carceralization is a modality of post-Cold War international regimes. International order is sought through the proliferation of instruments of international knowledge, surveillance, control and disciplinarization of elements of the international arena that are subjectified as 'delinquents'. However, while intensifying these governmental mechanisms, international organizations' political rationales and techniques of government do not succeed in normalizing delinquent states, but are met with multifarious strategies of resistance.

\section{Power and Resistance: The Structure of Human Interaction}

International normalization has been resisted in Croatia by local governmental agencies. Resistance has been exerted through the very spaces opened by international disciplinary endeavours in a variety of ways, spanning from accommodation to overt administrative obstruction. Before proceeding with the study of resistance in Croatia, I will define the conceptualization of resistance that underlies this analysis. Michael Merlingen argued that, by focusing on the productivity of power, governmentality theories 'tend to result in somewhat sanitized accounts of governance in which elements of domination, exploitation and violence (figurative and literal) become largely invisible' (Merlingen 2006: 191). Alternatives to governmentality theories', 'sanitized account' of power and resistance in international politics have recently been articulated in a body of literature that, inspired by Giorgio Agamben, focuses on the connections between sovereignty and biopolitics. This literature presents conceptualizations of power that emphasize domination and violence, and conceives of resistance as refusal and 'dispossession' (Edkins et al. 2004; Prozorov 2004, 2007). While both governmentality theories and the sovereignty-biopolitics literature ${ }^{4}$ claim to rely on Foucault, their conceptualizations of power and resistance are radically divergent. While governmentality relies on Foucault's elaboration of power as the 'relations brought to bear' (Hindess 1996), sovereignty-biopolitics scholars emphasize domination and oppression. Here, I explore how divergent understandings of Foucault's problematic of power elicit different conceptualizations of what counts as resistance and liberation.

In his analysis of power in Western political thought, Barry Hindess argued that Foucault's most relevant theoretical contribution is a distinctive understanding of power that takes distance both from theoretical traditions that conceive of it as capability (Hobbes) and traditions that see it as rooted in legitimacy and consent (Locke). In both of these traditions, power is understood 'as enhancing the capacity of those who possess it, and consequently, in so far as it impinges on other persons, as an imposition on the freedom of those persons' (Hindess 1996: 96). In these frameworks, power is a 'quantity' exerted 
on autonomous agents, and the research agenda focuses on analysing its effects on ontologically free, rational and moral individuals. Its effects are assessed in terms of the difference between the real and a postulated ideal (Hindess 1996: 149). Dwelling on these conceptualizations of power, critical theories (in particular the Frankfurt school) articulate the problematic of emancipation as part of the problematic of legitimacy: illegitimate power is the main obstacle to the achievement of individual autonomy. The critical referents of Hindess in this regard are Marcuse and Habermas. Regardless of their differences, both Marcuse and Habermas' conceptualizations of power and resistance rely on 'an image of the autonomous individual which provides an ideal against which the present can be measured; ... [and] the claim that such an ideal could be realized in a realm of social existence that is not structured by the illegitimate effects of power' (Hindess 1996: 95). In this context the subject (ontologically autonomous) and power (conceptualized along the lines of oppressive sovereignty) are defined by a relation of externality, where each is endowed with attributes and qualities that pre-exist their relationship. 'Emancipation' is then presented as an ideal condition of individual autonomy against the oppressive effects of social forces. Foucault moves away from this fixation with sovereignty and legitimacy and provides an elaboration of power as the ubiquitous feature of human interactions (Hindess 1996: 96-101). While for Habermas and Marcuse 'emancipation' presupposes a relation of externality between the subject and power, for Foucault the subject and power are interconnected. ${ }^{5}$ Exploring power is indeed a way of understanding 'the different modes by which, in our culture, human beings are made subjects' (Foucault 1982: 208). Resistance does not relate to power in an oppositional manner but in a transformative one. For Foucault, freedom is a practice in agonistic relation with power, not a natural condition of human life. Liberty and power stand in a relation of 'complicated interplay' (Foucault 1982: 221). In Foucault's own words,

At the very heart of the power relationship, and constantly provoking it, are the recalcitrance of the will and the intransigence of freedom. Rather than speaking of an essential freedom it would be better to speak of an 'agonism' of a relationship which is at the same time reciprocal incitation and struggle; less of a face-to-face confrontation which paralizes both sides than a permanent provocation (Foucault 1982: 221-2).

James Tully (1999) explored the implications of conceptualizing freedom as an agonic activity. Hannah Arendt (1977), well before Foucault, identified as one of the central problems of Western political thought the conceptualization of freedom along the lines of sovereignty: 'either the sovereign individual will in the Kantian tradition or the sovereign general will of the group in the Rousseauian tradition' (Tully 1999: 162). For Arendt, freedom is a social activity, having the potential for opening possibilities that were previously 
unknown, and emerge only as the result of political praxis. Tully explores the relevance of the notions of game play and game theory for an understanding of freedom that is not constructed based upon the image of sovereignty. Elaborating on Huizinga (1955), Tully argues that 'game playing ... is in fact freedom'. For Arendt, Huizinga and Foucault alike, freedom is a social activity, not an ontological attribute to the subject that can be sought outside social constraints (Tully 1999). ${ }^{6}$

In summary, as the structure of relations brought to bear, power is unstable, ambiguous and reversible. It does not entail eliminating liberty, and domination is only its extreme manifestation. In this framework, implied in governmentality theories, very little can be said about power in general. Here power must be studied in its contingent modalities and strategic interactions with resistance. Biopolitics-sovereignty scholars, relying on Giorgio Agamben's (1998) reading of Foucault, move away from understandings of power as an agonic, contingent and reversible structure of human interactions. Power is patterned along the metaphor of sovereignty, and the focus shifts from strategic interaction to domination (Edkins et al. 2004; Prozorov 2004, 2007). ${ }^{7}$ Agamben (1998) sees the Nazi concentration camp as the paradigm of modern power, where the coupling of sovereignty and biopolitics produces violent and totalizing effects. Here the subject is stripped from political life, to be reduced to 'bare life', that is life excluded from juridical order. Building on Agamben, Prozorov (2007: 107) argues that modern power is a totalizing project that abducts human existence in all its aspects. 'When sovereign and biopolitical powers are combined, we ... deal with ... a genuinely absolute abduction of human existence that mends all separations and no longer excludes anything from its operations'. For Prozorov freedom is ontologically 'anterior and exterior to any form of positive order' (Prozorov 2007: 10) and essentially antagonistic to it. All discourses of power 'sacrifice the experience of freedom by turning human existence into a project' (Prozorov 2007: 9). Prozorov envisages two ways out of the totalizing inscriptions of liberal power. On the one hand, building on Schmitt, Prozorov situates the exit point in the sovereign act of decision on exceptions through which the foundation of political order is established (Prozorov 2004). ${ }^{8}$ On the other hand, he identifies resistance as 'bottom up' individual acts of total rejection of the inscriptions of biopolitics (Prozorov 2007). Thus, the most radical aspect of Foucault's elaboration of resistance is recasting 'freedom in terms of dispossession', that is, weakening power by refusing its care. In this perspective, which is shared by other scholars such as Edkins and Pin-Fat, resistance is articulated as absolute rejection of the diagram of power, its 'drawing lines'. As Edkins and Pin-Fat (2004: 12-13) would have it,

since sovereign power relies on two things- first, the drawing of lines between forms of life and, second, the production thereby of a generalized 
bare life- there are two ways in which the demand for a return to politics can be articulated: first the refusal of sovereign distinctions and the acceptance of bare life.

Here, resistance is conceptualized as the sovereign's act of foundational creation, or as the individual's total rejection of power rather than an agonistic game of contestation where both power and resistance are continuously reformulated. Political life consists of escaping power through acts of 'dispossession' by which humanity will achieve 'the end of the exodus of the subject of freedom from the diagram, the recovery of one's potentiality for being from its biopolitical confinement' (Prozorov 2007: 146). ${ }^{9}$ Liberated from all constraints, diagrams and inscriptions, a freed humanity will live in a world of pure possibilities: 'Elated by the infinite expanse of possibilities now available to him [sic], he [sic] breaks into a run, eager to return to a life he [sic] never had' (Prozorov 2007: 152). The subject, for Foucault constituted within contingent relations of power and resistance, comes back here in full force as an ontological a priori endowed with freedom. As a new end of history is envisaged, both power (conceptualized along the lines of sovereignty) and the autonomous rational individual become the referents for grand narratives of oppression and liberation, and universal prescriptions for reaching freedom. Not surprisingly, for Prozorov, governmentality studies are a mere redescription of liberal discourses of governance: 'because they do not foresee an opening onto the exterior of the diagram [of power] they do not have much to say about the problematic of resistance' (Prozorov 2004). Prozorov's conceptualizations of resistance and liberation remain trapped into understandings of power as capacity and legitimacy in a relation of externality with the subject. The research agenda that emerges here is concerned with asking 'why the postulated ideal conditions do not exist' (Hindess 1996: 149). Instead, research agendas generated in the context of governmentality theories focus on 'what happens' and explore practical questions on the modalities of deployment of power. Here the problematic of freedom is studied as an articulation of the problematic of liberal governance, rather than as the measure of the gaps between a real and an ideal condition of humanity. As Nikolas Rose (1996: 61-2) writes,

Freedom ... is no 'natural' property of political subjects, awaiting only the removal of constraints for it to flower forth in forms that will ensure the maximization of economic and social wellbeing. The practices of modern freedom have been constructed out of an arduous, haphazard and contingent concatenation of problematizations, strategies of government and techniques of regulation. This is not to say that our freedom is a sham. It is to say that the agonistic relations between liberty and government is an intrinsic part of what we have come to know as freedom. 
In summary, the focus of governmentality theories is not to explore the conditions of freedom, or to construct romanticized rhetoric of rejection as ways for escaping or subverting domination. Governmentality interrogates tactics and practices of power. It does not propose apocalyptic or totalizing views, cast an entirely negative judgment on all power manifestations (Larner and Walters 2004a, b), or, for that matter, attach an unqualified liberation power to resistance. In a governmentality framework, the exercise of freedom (intended as agonistic political struggle) is not reached through acts of total rejection, be they rooted in the sovereign's foundational decision on exception or in the layman's total refusal of power's inscriptions. More modestly, the struggle for freedom is sought through activities and modalities of inquiry that 'unsettle the obvious' of idioms and practices of power. If (contingent) possibilities of unsettling the inscription of the diagram are possible, they result from inquiries that explore the formation of idioms of government (and resistance), question their universal normative claim and denaturalize their accepted practices. As Nikolas Rose (1999: 10) writes, 'the destabilization of our ethical repertoire is an ethical work upon ourselves'. Instead of prescribing paths for liberation, governmentality provides 'tools of inquiry in the hands of those who question the universal validity of our current practices' (Rose 1999: 19). It is this methodological concern that makes governmentality studies very different from the biopolitics-sovereignty literature, from liberal accounts that take prevailing discourses and idioms for granted and from sociologies of rule that focus on identifying established patterns and regularities. ${ }^{10}$

By adopting a governmentality approach to analyze the case of Croatia, this study questions both 'a social ontology that converts boundaries and standards central to modern life into precepts of rationality, morality or self realization' (Connolly 1987: 9), and romanticized conceptualizations that unreflectively attach liberation or 'emancipatory' qualities to resistance. It brings to light the normalizing effects that international political rationalities produce, the contestation they elicit and the ambiguous outcomes of interplay between power and resistance. One of the implications of conceptualizing resistance as an agonistic activity imbued with power is that no uncontested ethical value can be unreflexively attached to it. As opposed to romanticized images that portray resistance as an 'ethically good' activity of the powerless against the powerful, resistance may very well deploy new modalities of oppression. As this study shows, if looked at from the standpoint of the Serb minority, the Croatian government's resistance to the inscriptions of international power did not particularly entail liberation.

\section{Normalizing Croatia through International Peace Agreements and Euro-Atlantic Integration}

In Croatia, numerous international organizations intervened to carry out the normalization of the country through disciplinary and governmental 
mechanisms. Here I explore these processes from the establishment of the United Nations Transitional Administration in Eastern Slavonia (UNTAES) until the admission of Croatia as a candidate to the EU. At the onset of UNTAES, the United Nations brokered a peace agreement, known as the Erdut agreement, ${ }^{11}$ that set the framework for international normalizing, disciplinary and governmental practices. The central organizing idiom for the Erdut Agreement's mandate of UNTAES and the Croatian government's longterm conduct was 'respect of human rights'. The territorial integration of Eastern Slavonia was carried out in exchange for respect of the rights of the Serb minority. In addition, the Peace Agreement, by establishing specific benchmarks to be achieved and administrative arrangements to be undertaken, translated the general principles it stipulated into a governmental mechanism. The Erdut Agreement established the basis for disciplinary processes of transformation of Croatian institutions. It elicited the government's active engagement in this transformation and the continuous tutorship, examination and assistance of international organizations. It also institutionalized international scrutiny by establishing an international diplomatic body for monitoring performance.

The Agreement consists of three sections. The first regards short-term provisions for the administration of Eastern Slavonia under the United Nations Transitional Administration (Articles 1-5 and 12); the second includes provisions of general validity regulating the protection of human and civil rights (Articles 6-9); and the third includes provisions regarding the monitoring of the implementation of the Agreement after the withdrawal of the Transitional Administration (Articles 10-11) (Correl 2001). ${ }^{12}$ The first set of provisions entrusted UNTAES with the tasks to be carried out during the transitional period. These were restoring public services, training and building professionalism in the police, organizing elections and facilitating the appointment of a local Serb self-government. The second section of the Agreement not only established Croatia's benchmarks with regard to human rights, but also translated general idioms into specific policy prescriptions. Croatia was to respect the "highest standards of internationally recognized human rights and fundamental freedoms'. This meant, specifically, that all those who left the region had the right to return; that all those who came to the region and were previously permanent residents of the Republic of Croatia had the right to stay; that the same standards of human rights should apply to all, regardless of ethnicity; that all those whose property was illegally taken or who were forced to abandon it had the right to repossess it, receive compensation or assistance for reconstruction.

The third section of the Agreement established international disciplinarity as an open-ended modality of international governance that would exceed the goals of peacekeeping. It detailed mechanisms for monitoring the 
implementation of the Agreement's provisions after the withdrawal of UNTAES, and for reporting on progress. In this regard, it stipulated that 'after the expiration of the transition period and consistent with established practice, the international community should monitor and report on respect of human rights in the Region on a long-term basis'. In addition, it constituted a diplomatic body, known as the Article 11 Commission, in charge of monitoring 'the implementation of ... [the Erdut] Agreement, particularly its human rights and civil rights provisions, to investigate all allegations of violations..., and to make appropriate recommendations' (Articles 10-11). The Article 11 Commission was steered by the United Nations Liaison Office (UNLO) and was open to major international organizations and bilateral diplomatic representations present in Croatia. The Commission was a loosely institutionalized dispositif for monitoring and steering policy. Membership was open but not mandatory. ${ }^{13}$ The Commission established a forum for sharing idioms and devising specific strategies for applying political pressure on the government. Meetings were called on an ad hoc basis and held at the UNLO or at bilateral embassies. Most often, preparatory discussions were held informally at diplomatic gatherings or dinner tables. However, the Commission was not a unitary agent of domination. While its members used concepts of human rights as stipulated in the Erdut Agreement, they often emphasized different sets of priorities and were divided along the lines of bilateral agendas upon the question of which topics should be raised with the Croatian Government. For example, the German ambassador was stricter than the Spanish ambassador on the issue of property repossession, while Italy linked the issue of Serbian repossession of property to the restitution of Italian property expropriated in Istria after World War II. ${ }^{14}$

Disciplinarity requires the active engagement of its subjects in the process of their transformation, defines benchmarks and goals, and monitors compliance. In a letter to the President of the Security Council (known as 'Letter of Intent'), subsequently attached as an annex to the Erdut Agreement, the Croatian government committed to respect the conditions stipulated therein. Additionally, it defined the benchmarks to be achieved, and submitted the process of transformation of its institutional arrangements to continuing international scrutiny (United Nations Security Council 1997a). The Letter stipulated the administrative arrangements for minority representation in bodies of local government and public services in the Danube region. Accordingly, the Serb minority would be entitled to proportional representation (including in senior positions) in local health services, police and judiciary. Furthermore, the posts of Sub-Prefect in the counties of Osijek-Baranja and Vukovar-Srijem would be reserved for a Serb. The Letter went into such detail as 'for at least the first year following local elections, the number of local police from the Serb and other non-Croat ethnic communities shall be approximately 700 to $800^{\prime}$ 
(United Nations Security Council 1997a: para 4). The number of seats to be reserved for national minorities in the House of Representatives and the Parliament would reflect the next census results. The Joint Council of Municipalities was recognized as the representational body of the Serb Community. Serbs were assigned to senior posts in the Ministry of Reconstruction and Development, and the Office for Displaced Persons and Refugees (ODPR) as well as 'at a level no lower than Assistant Minister in the Ministry of Interior, Justice, Education and Culture' (United Nations Security Council 1997a: para 7). The Croatian government also recognized the right to educational and cultural autonomy, in line with what was established in other annexes to the Erdut Agreement. ${ }^{15}$ It acknowledged that minorities had the right to be educated in their language and script; that existing schools could not be amalgamated without consultation with minority representatives; that a moratorium on teaching the history of the former Yugoslavia between 1989 and 1997 was to be in effect for 5 years; that diplomas earned under the Krajna rule would be valid; and that school principals' ethnic representation would be proportional to the demographic composition of society. In addition, the Croatian government restated its commitment to defer military service for members of the Serb community.

In his final report on UNTAES, the United Nations Secretary-General, while recommending the withdrawal of peacekeeping forces, indicated that the process of normalization that started during the United Nations Transitional Administration was the first step in a long-term transition that required, in addition to Croatia's commitment, the continuing joint effort of international actors in monitoring its performance and assisting its transformation. As normalization was not yet accomplished, international disciplinarity should continue. In the Secretary-General's words, while 'the political and institutional framework for the reintegration of civil administration ... was finalized' (United Nations Security Council 1997b: para 2), the reintegration of public services and enterprises was by and large completed, the principle of proportionality in public employment mostly respected, and demilitarization accomplished, a number of administrative arrangements that had been stipulated in Erdut and its annexes were yet to be implemented. The integration of the education and health care system was still problematic and so was the reintegration of the social welfare system, especially the recognition of years of work under the Republika Srbska Krajna. The report also underscored the fact that the Erdut Agreement's stipulations were met by the local political constituencies' resistance through administrative obstruction. In the Secretary-General's words, Serbian returns and reintegration was inhibited by three factors: 'legal and financial obstacles to the recovery of property; unrealistic government deadlines for Serb application for reconstruction assistance and delays in government funding for reconstruction of Serb 
houses; and the uncertain economic and social situation in the areas of potential return' (United Nations Security Council 1997b: para 5). In addition, there were reasons for concern regarding the application of the Amnesty Law and the fairness of trials for human rights violations when the accused were Serbs. In summary, the administrative instruments through which the international agencies intended to bring about the normalization of Croatia through disciplinary mechanisms had also become the spaces for exertion of resistance by local political constituencies.

The Secretary-General reiterated that international agencies should continue to steer Croatia's governmental practices and set the agenda by spelling out which matters needed the Croatian government's most urgent attention. These were administrative reforms concerning a vast array of aspects of population life, such as social welfare, education, refugee returns and local government. ${ }^{16}$ In order to translate general aspirations into tools for international governance, the Secretary-General included in his report a list of annexes to the Erdut Agreement by which Croatia committed to undertake specific administrative reforms, thus establishing specific benchmarks subject to international scrutiny and assessment. The list includes, in addition to the Erdut Agreement and the Letter of Intent, 25 agreements covering in capillary detail a vast array of aspects of public administration. These include labour rights, the ethnic integration of public utilities and communication networks into the Croatian system, the integration of health and education institutions, the integration and issuing of public records, the welfare and pension system, the establishment of minority representation bodies, the integration of the judiciary and the police and a number of minority return-related matters. ${ }^{17}$ By annexing these sub-agreements to the report that established UNTAES' withdrawal, the Secretary-General instituted their continuing validity and reinforced the peace agreement stipulated in Erdut as an enduring governmental instrument in the hands of international organizations. Indeed, by subscribing to these agreements, Croatia accepted international governmental intervention and made itself permanently 'internationally accountable':

Taken together with the provisions of the Croatian Constitution, those agreements for which Croatia has made itself internationally accountable, provide a comprehensive political and institutional framework of guarantees, which, if fully implemented, will allow the people of the region to exercise freely their rights and obligations as equal citizens of Croatia (United Nations Security Council 1997b: para 7).

The process of normalization of Croatia through international disciplinary and governmental mechanisms continued, as prescribed by Kofi Annan, after the withdrawal of the United Nations peacekeepers. Until June 2003, the United Nations continued to directly monitor the implementation of the Erdut 
Agreement in Croatia through its liaison office in Zagreb. Issues of minority rights, returns and reintegration, property repossession and reform of the judiciary were also included in the mandates of the United Nations High Commissioner for Refugees (UNHCR) and the Office for the High Commissioner for Human Rights (OHCHR), in addition to a number of local and international NGOs. The Organization for Security and Cooperation in Europe (OSCE) reported on compliance with the human rights provisions of the Erdut Agreement. These agencies monitored and promoted the normalization of the Croatian state by deploying an array of mechanisms, including, in addition to the processes of accession to Euro-Atlantic structures, advisory activities to the central government with regard to legal reform; diplomatic démarches by the Article 11 Commission on specific issues regarding minorities; informal lobbying; advising local administrations and redesigning judiciary systems; advocacy activities and legal support for minorities.

Legal reforms were among the main instruments of international organizations for normalizing Croatian governmental processes, that is, making them abide by internationally established benchmarks of minority human rights. In June 2001, at the initiative of the OSCE, a Joint Legal Working Group (JLWG) was established to advise the government on reforms pertaining to the return and reintegration of minorities and to support the diplomatic activities of the Article 11 Commission. The JLWG (which included representatives of the Croatian government and experts of the UNLO, the OSCE, the EU and the UNHCR) met periodically to discuss these matters. ${ }^{18}$ Its international component provided verbal advice and detailed working papers on laws concerning issues such as the establishment of a comprehensive regime for the repossession of the housing property taken from the Serb minority during the 1991-1995 conflict; the establishment of guarantees with regard to transparent and efficient administrative procedures for the return and legalization of former habitual residents of Croatia; the promotion of proceedings to compensate for damages caused by Croatian armed forces during the war; the non-discriminatory implementation of the law on reconstruction; and the clarification and transparent implementation of the convalidation of years of work under the Republika Srbska Krajina (RSK) for retirement purposes.

The closure in June 2003 of the UNLO (the symbolic custodian of the Erdut Agreement and the last vestige of UN peacekeeping) marked, in international eyes, the conclusion of the process of the pacification of the country. However, international organizations, including the OSCE, the EU and NATO, continue to monitor the Agreement's implementation and to deploy a combination of disciplinary and governmental means to monitor, tutor and steer Croatia's normalization. In addition, the Community for Reconstruction, Development and Stabilization (CARDS) programme, guided by the Council of Europe, provides financial and technical assistance, and legal reforms regarding 
minority rights are coached by the European Commission for Democracy through Law (the Venice Commission). ${ }^{19}$ Reports are prepared, statistical information collected, funds invested, advice provided and assistance given in order to make Croatia a democratic and 'normal' country by European standards. Assimilation is promoted through scrutiny, standardization, examinations and reward/punishment mechanisms. Government by community is a key tool in the hands of international Euro-Atlantic organizations. In order to be included, states must become normally functioning elements of the 'international community', capable of active self-management, performing market economies, liberal democracies with predictable administrations and responsible protectors of the health and wealth of their citizens.

For Foucault, discipline is both standardizing and individualizing. In order to be made a responsible element of a group and achieve standards of performance that are valid for all, diverse individuals are assisted with tailored programmes designed to accompany their personal transformation from deviance (or disease) into normality or health. To achieve these results, an array of savoirs and techniques (for instance, criminal psychology, penitentiary literature, clinical medical science, military training) emerge that treat the individuals to be transformed as unique entities with their own specific characteristics and path of 'development', but also include them in fields of comparison and standardization. This could be seen in the case of Croatia.

Croatia signed the Stabilization and Association Agreement on 29 October, 2001, and submitted its application for membership to the EU on 21 February, 2003. In April 2004, the European Commission issued a positive opinion on Croatia's application (Commission of the European Communities 2004). In December 2004, the European Council endorsed the Commission's opinion and Croatia became a full candidate to the EU in October 2005. The conditions for the association of Croatia with the EU stipulated in the Stabilization and Association Process (SAP) (Commission of the European Communities 2002) continued and intensified the processes of normalization set in place in UNTAES. The SAP reinforced international governmental tools in the hands of international actors through the definition of multiple benchmarks and modalities for assessing progress with regard to respect of human rights, democracy and liberalization of the economy. It also emphasized continuity between procedures of pacification and procedures of normalization: '[The SAP] underpin[s] the implementation of the Dayton/Paris and Erdut agreements and bring[s] basic stability and prosperity to the region' (Commission of the European Communities 2002).

The process of accession of South Eastern European Countries to the EU established in the SAP is set out as a disciplinary project that combines elements of reward and punishment, surveillance and training, examination and assistance, and standardization and individualization. ${ }^{20}$ South Eastern 
European countries are provided with incentives for reform by offering a 'credible prospect for membership once the relevant conditions have been met' (Commission of the European Communities (undated)). In order to be admitted, each 'potential candidate' has to undergo periodical examinations: 'Effective implementation of the Stabilization and Association Agreements is a prerequisite for any further assessment by the EU of the country's prospects of accession' (Commission of the European Communities (undated)). The SAP aims at obtaining standardized results through individualized methods. On the one hand, each country must 'achieve the adoption of European standards'. In this regard, 'the destination for all countries is expected to be the same: the full realization of association after a transitional period through implementation of the same core obligations' (Commission of the European Communities (undated)). On the other hand, each Stabilization and Association Agreement is signed individually and 'tailored to the circumstance of each country'. The EU plays a role similar to a tutor, a trainer or a psychologist to guide each individual country to normality: 'the EU will work with each country to bring them closer to the standards which apply to the EU' (Commission of the European Communities (undated)). As any personalized training or programme, the 'Stabilization and Association process is ... designed to be a flexible and dynamic process, evolving in line with changes in the region, the EU and the world' (Commission of the European Communities (undated)).

Idioms of democracy and respect for minorities are, together with economic criteria and adherence to European political, economic, monetary and administrative standards, the benchmarks to be achieved to meet the conditionality for Croatia's admission into Europe. ${ }^{21}$ In expressing its positive opinion on Croatia's accession to EU candidacy, the Commission emphasized that Croatia's democratic institutions are 'stable', that they 'function properly' and that the 2002 and 2003 elections were 'free and fair'. While acknowledging that fundamental rights are by and large respected, the Commission underscored that more must be done with regard to Serb minority rights and judicial reform, and for the implementation of laws improving the functioning of institutions.

With regard to the economic criteria, the Commission indicated that Croatia is a functioning market economy. However, it recommended reforms aimed at extending mechanisms of standardization, visibility and simplification to an array of issue-areas still affected by legal and administrative confusion. In this regard, establishing a comprehensive property record system, clarifying administrative functions, unifying systems for taxation and improving the performance of the judicial sector are considered the main priorities. The extension of consistent, clear and continuous mechanisms of government is not only the main foundation for the 'good governance' of each single state, but it is also the precondition for accession to supra-national structures. Normalized states need stable legal processes and unified administrative mechanisms in 
order to become legible, visible and governable for international institutions. Issues of 'good governance' or governability through standardized administrative processes and unified systems are considered key elements for Croatia's capacity to carry out the EU requirements.

Processes of visibility and simplification are matched by the intensification of mechanisms of international surveillance necessary to accompany Croatia in its process of normalization. The Commission emphasized that:

To assist Croatia in the preparation of accession negotiations, a comprehensive screening exercise would need to be undertaken ... This Opinion is accompanied by a draft European Partnership for Croatia which identifies the priorities which it needs to address in preparing for accession. The Commission will report regularly to the Council on the progress made by Croatia on its preparation for EU membership (Commission of the European Communities 2004: 20).

The international commitment to make Croatia visible, legible and governable is exemplified by the United Nations Development Programme's (UNDP) development of a system of statistical data-collection in line with the EU's Nomenclature Territory of Statistics (NUTS) (United Nations Development Programme 2003). Statistics, as Foucault has shown, was a central savoir in the construction of governmentalized practices of government based upon knowledge and administration of territory of population (Foucault 1991a,b). Statistics made an array of local processes legible and governable to central administrations. For the UNDP, the implementation of a statistical system compatible with European standards would not only facilitate Croatia's administrative capacity and ability to carry out its commitments to the EU, but also ease the implementation of international governmental mechanisms through the EU's regional development policy. ${ }^{22}$ The criteria for the collection of information had to be standardized, and Croatia had to be included in a field of comparable elements. 'Croatian counties, municipalities and towns' will have to be classified 'according to the model used by the bearers of the European Union's structural policy and of Member States' regional policies' (UNDP 2003: 20). This process was not unproblematic. The introduction of the NUTS system in Croatia required that decisions be taken with regard to the administrative organization of the territory, and that this organization be clarified and stabilized. ${ }^{23}$ However, the UNDP report underscored the fact that the numerous changes that had taken place in the last 50 years in the territorial organization of Croatia made the collection of consistent and standardized information particularly difficult. ${ }^{24}$ Some of the territorial arrangements required by the EU statistical system antagonized local political interests and were actively obstructed by local constituencies. This was the case, for instance, when the redefinition of territorial units to accommodate European standards 
would affect the calculation of the presence of refugees in certain regions and therefore the continuation of international subsidies to those areas.

The process of association with NATO was carried out through idioms and techniques very similar to the ones adopted by the EU. These are standardization and individualization, advice and counselling, periodical examination and mechanisms of reward/punishment. The NATO Membership Action Plan (MAP) is a NATO program of advice, assistance and practical support tailored to the individual needs of countries wishing to join the Alliance' (NATO 2004). It includes a broad range of activities for the aspiring members who must voluntarily subject themselves to continuous scrutiny, counselling, examination and rehabilitation with regard to political and technical matters:

The MAP's main features are the submission by aspiring members of individual annual national programmes on their preparations for possible future membership, covering political, economic, defence, resource, security and legal aspects; a focused and candid feedback mechanism on aspirant countries' progress on their programmes that includes both political and technical advice, as well as annual meetings between all NATO members and individual aspirants at the level of the North Atlantic Council to assess progress; and a defence planning approach for aspirants which includes elaboration and review of agreed planning targets (NATO 2004: 1).

Progress towards internationally established benchmarks is assessed in the yearly meetings of the North Atlantic Council with individual aspirants. Nevertheless, counselling and training are continuous: 'Throughout the year, meetings and workshops with NATO civilian and military experts in various fields allow for discussion of the progress report on activities under the MAP' (NATO 2004: 1).

The idioms and the techniques for steering and modifying behaviour, used by the UN, the EU, the UNDP and NATO, are isomorphic but not centralized. Representations of international organizations as coherent actors fail to grasp the innovative and specific modalities through which regimes of practices of international government are deployed. In contrast to notions of power as domination, post-Cold War international regimes of practices work by deploying multiple but isomorphic instruments, and by mobilizing the cooperation and active engagement of their targets in their own transformation (Brigg 2002).

\section{Resisting International Normalization}

The international deployment of different means of normalization and disciplinarization was matched by the local constituencies' differentiated strategies of resistance. Resistance was not carried out through simple acts of 
rejection of all inscriptions of international power. On the contrary, resistance was often coupled with accommodation and exerted in complex ways, through the very administrative instruments set in place by international actors.

The JLWG became not only an instrument for the international institutions to foster legislation amendments, but also a locus where the Croatian government deployed strategies of partial accommodation and/or hijacking of the international agenda. The latter included deferring discussion of key issues, providing the JLWG meetings with statistics and data that were virtually non-understandable, participating with officials with no decisionmaking power, deferring discussion of key topics of the agenda by focusing on marginal issues and passing legislation that was part of the JLWG agenda without consultation with the group. For instance, in January 2003, the Croatian government forwarded to the parliament three laws on compensation of damages caused by the Croatian armed forces without consulting with international partners. The international members suspended the JLWG until further notice in protest of the Croatian government's lack of commitment. ${ }^{25}$

In some other cases, international organizations and diplomatic bilateral representatives were able to regulate Croatian administrative arrangements and to force compliance with the benchmarks established in the Erdut Agreement. For instance, in 2001, when the Croatian government started a policerestructuring programme in Eastern Slavonia, the Article 11 Commission took an official démarche ${ }^{26}$ with the Ministry of Interior to request compliance with the principle of ethnic proportionality established in the Memorandum of Understanding (MOU) on the Restructuring of the Transitional Police Force in the UNTAES region. ${ }^{27}$ In its démarche, the Article 11 Commission requested respect for proportionality in all police command positions in Eastern Slavonia and went on to indicate that, in line with Croatia's international commitments, 15.78 per cent of uniformed police personnel in Eastern Slavonia should be Serbs. In practical terms, that meant adding a further 101 Serbs to the ones who were already planned for by the Ministry of Interior. However, the international 'success' remained limited in scope. As of November 2005, the Eastern Slavonian police force remained the only multi-ethnic one in Croatia. ${ }^{28}$ At that time, national minorities were still underrepresented in the police workforce, where only 2 per cent were from minority groups (as compared to 7.5 per cent in the population) (OSCE 2005).

In most cases, international governmental and disciplinary efforts were met with a mixture of formal accommodation and practical sabotage. On 13 December, 2002, under pressure from international counterparts, the Croatian parliament adopted the Constitutional Law on the Rights of National Minorities (CLNM). This law provided that multi-ethnicity should be observed in administrative and judicial bodies, including the police, in all Croatian territories. A step in the implementation of the CLNM was the adoption, in 
March 2003, of the Electoral Legislation for Local and Regional Bodies. ${ }^{29}$ In line with the provisions of this legislation, elections for minority councils were held on 18 May. However, the timing chosen by the government for these elections, called at short notice and held in the immediate aftermath of a long period of vacation connected with the Catholic and Orthodox Easter, was not designed to favour widespread participation. Voter turnout was rather low throughout the territory. Serbs and Roma were among the minorities that participated the least. The Law on Terrorist Act, regarding compensation for property destroyed during the conflict by the Croatian army, is another instance of accommodation and sabotage. In July 2003, the Croatian Government passed the Law on Terrorist Act under pressure from the international community. However, at the same time, the government declared many premises not eligible for compensation and very few owners were able to receive reconstruction assistance.

While the central government, concerned with scoring political points internationally in view of Croatia's accession to the EU, made efforts to accommodate international demands, local administrations, especially in the areas where the conflict was fierce and ethnic resentment high, tended to obstruct the implementation of all legislation going against the interests of their constituencies. The issue of restitution of the housing properties expropriated from Serbs during the conflict is high on the agenda of the international normalization of Croatia. This is a very touchy political problem, especially for Croatian local administrations. During the operation Flash and Storm, through which Croatia regained the Serb-controlled areas, more than 170,000 people of Serb ethnicity were displaced into Bosnia and Herzegovina, and Serbia and Montenegro. Immediately after Flash and Storm, the Croatian Government passed the Law on Temporary Take Over and Administration of Specified Property (LTTP) that provided that those who had fled and did not return within 90 days would lose the right to reoccupy their residences. By means of this legislation, the government took over about 18,500 houses occupied mostly by Croatian Serbs who had fled the area. It then reallocated these houses to Bosnian and domestic Croats, including Internally Displaced Persons (IDPs) and settlers (Ministry of Public Work, Reconstruction and Construction January 2003). By the end of 2002, the government and its international partners had reconstructed some 188,000 houses out of 196,000 that were destroyed during the conflict. However, the 111,000 houses reconstructed by the government were allocated almost exclusively to Croats. Discriminatory provisions included in the 1996 Law on Reconstruction with regard to allocation of funds made this possible (ICG 2002).

Throughout the process, local administrations resisted the implementation of legislation that could harm their political constituency. Court decisions were taken at a very slow pace and evictions of Croats were rarely executed unless 
alternative accommodations were available for them. An example of court delay in this regard is the case of 79-year old Serb Nikola Kljajic who had been waiting for housing repossession for 8 years. Despite the fact that the court ruled in his favour in 1999 and 2004, as of April 2006 Kljajic was not able to repossess his home due to lack of enforcement of the court's decision (OSCE 2006). In addition, even when houses have been repossessed, owners have often found them looted and have had no recourse to recover damages, other than starting a costly private lawsuit with little chance of success. Local administrations' policy with regard to access to utilities when the applicants were Serb families is another instance of obstruction: in many cases returnees were not able to get utilities reconnected unless they paid the former occupants' outstanding bills. Some areas inhabited by minorities were not provided with basic services such as road maintenance or snow plowing.

In 2002, in response to complaints about the ineffective and discriminatory practices of the local Housing Commission, the government centralized the housing repossession process at the ministerial level. Since then, Croatian Serbs have represented the majority of the beneficiaries of the Government's reconstruction programmes (OSCE 2004). With the exception of about 200 cases still pending, the property repossession process was completed in 2005 (OSCE 2005). However, local constituencies' administrative obstruction has made repossession difficult to sustain. As of 2006, only 25 per cent of the property returned was inhabited by the prewar owners (OSCE 2006). Property rights are part of commonly accepted liberal legal language. However, in Croatia, socially-owned flats further complicated the housing repossession issue. In the former Yugoslavian urban areas, families were entitled to live in socially-owned flats as part of their work benefits. Serbs who fled their homes during the war were deprived of these rights, either on the basis of an absence of more than 6 months (as established in prewar legislation) or on the basis of the 90-day deadline for return set in the LTTP. In a time of conflict, these deadlines were difficult to meet. For years, the Croatian government had resisted addressing this category of apartments, and the international actors, not having a consolidated legal ground on which to base their claims, were less vocal in advocating restitution. By April 2006, notwithstanding the government's declaration of intent, accommodation still had to be found for the approximately 30,000 Croatian Serbs who had lived in socially-owned apartments (OSCE 2006).

Unintended consequences are also at play. The territorial limitation of the provisions of the Erdut Agreement produced ironical effects. Because in the UNTAES region occupancy rights were not cancelled, the mostly Croat returnees were able to regain their houses. The same was not true for those Serbs who were displaced into the UNTAES region during the war and attempted to return to their homes in other areas of Croatia. Returns to the 
Danube region were mostly 'majority returns'. By stating the right of all to their residences, the Erdut Agreement protected the rights of the Croat majority whose homes where occupied by minority Serbs. However, as its provisions were territorially limited to Eastern Slavonia, the Erdut Agreement offered no remedy for the Serbs who were evicted from the Danube Region but were not able to repossess property in other parts of Croatia. Attempts to deal with the issue of returns were reflected in the 2005 implementation of the 'Sarajevo Process' by which Croatia, Serbia and Montenegro indicated their commitment to finding a regionally integrated solution to the problem of displaced people. The progress of the Sarajevo Process has, however, been very slow.

The use of administrative means to resist minority reintegration is not limited to the housing issue. Under the Yugoslav state, citizens who were not born within, but who were working and living within, the administrative borders of what later became independent states were considered to be habitual residents and had full right of residence. After secession, this right was often refused to Serbs attempting to return to Croatia. Furthermore, as Croatian citizenship legislation allocates preference on the basis of ethnicity, ethnic Croats who had never resided in Croatia before the conflict easily obtained citizenship, while Serbs and other minorities who used to be permanent residents continue to face obstacles. These obstacles are aggravated by the slow response of local administrations to minority demands for personal records and identification documents, necessary to exert rights in a modern state bureaucracy.

Notwithstanding the conditions stipulated in the annexes to the Erdut Agreement, the Croatian social welfare system continued to delay the full implementation of the 'Law on Convalidation' passed by the Parliament in October 1997. This law provides for the recognition of the years worked under the RSK for retirement purposes. The lack of recognition of those years of service makes unavailable the only source of basic income for thousands of Serb former employees who would otherwise be eligible for pension. International agencies assessed Croatia's progress towards normalization as sufficient to be admitted as a candidate into the EU. While ethnically motivated physical confrontations or threats to life are rare, in areas where the process of returns is still under way, Serbs face verbal harassment and arrests for alleged war crimes that often remain unsubstantiated. In areas heavily affected by conflict, such as Eastern Slavonia, Serbs and Croats still carry on separate lives and send their children to separate schools. While the miltary conflict is over, the war of looks and words is still ongoing. ${ }^{30}$ The nationalist agenda remains appealing to many who were involved with or have been affected by the war. In August 2005, street protests followed the capture of Gotovina, an ICTY-indicted war criminal who is seen as a hero by many in the 
region. Such incidents may signal that the multifarious techniques of administrative and legal normalization deployed by international actors are not matched by normalization of internal political processes.

As William Connolly (2004) has argued, legal language does not determine court decisions, while culture, ethos and social acceptance resist normalization and escape totalizing processes. In Croatia, international normalization inscribed modalities of subjectification through the continuous refinement and redeployment of international mechanisms to scrutinize, assess and transform the state. These, in turn, foster the opening up of new spaces for resistance and agonistic political endeavours. However, as the analysis of the interaction between international power and the practices of the Croatian government has demonstrated, processes of local resistance are not necessarily conducive to the liberation of subjugated minorities.

\section{Transparent Regulations, Opaque Politics: Reflections on Power, Resistance and Liberation}

In Croatia, international agreements signed in the context of peacekeeping constitute the starting point of a normalizing process that continues beyond the withdrawal of the Blue Helmets under the umbrella of regional organizations such as the EU, NATO and the OSCE. These organizations rely on the Erdut Agreement's idioms, stipulations and prescriptions to set in place and expand benchmarks, rules, regulations, monitoring, assistance, assessment and reward/ punishment mechanisms. International organizations attempt to regulate and normalize the conduct of state institutions and local administrations through the multiplication of disciplinary techniques. These processes have been accommodated and resisted by Croatian government agencies through the very instruments deployed by the international bodies. The strategies are multifarious, the outcomes mixed and the political effects uneven. The tactics of the central government for sidestepping the advice of the JLWG, the local administrations' lack of implementation of eviction orders when the illegal occupants were Croats, the slow recognition of pension rights for Serbs and the difficulties Serbs encounter in obtaining citizenship and identification documents constitute examples of this resistance. When international demands with regard to minority rights could not be satisfied without hurting the interests of ethnic Croats, they were hijacked by local administrations.

Croatia's multifarious modalities of resistance indicate that political will cannot easily be created through regulatory processes and that there is continuous tension between local political dynamics and international disciplinary agendas. Political will (or the lack thereof) continues to blur the enforcement of multilateral plans. New spaces for agonistic political moves are opened through the deployment of these very mechanisms. International regimes of 
power produce carceralization (which is continuously resisted and redeployed), not domination (which, in Agamben's terms, reduces political life to bare life and thereby makes political contestation impossible). International carceralization does not attain normalization of 'deviant' states, but the creation of a never-domesticated population of 'delinquents'.

While conceptualizations of power as the structure of human interaction unsettle the notion (rooted in Western philosophical tradition) of an autonomous rational and moral subject prior to any contingent social relations, they do not lead to deterministic visions of political life. There are no overarching effects of oppression in power inscriptions, or guaranteed outcomes of liberation in strategies of resistance. Instead, actors (be they individuals or states) are the result of processes of subjectification whose effects are never over determined, always open-ended and negotiated in the continuous struggles between modalities of power and strategic acts of resistance. In this context, research agendas that question totalizing discourses of any kind play a role in opening the way for modest agonistic political activities that are not founded on radical rejection or utopian idealization, but in practical inquiries about 'what happens'.

\section{Acknowledgements}

I am indebted to Tim Luke, Scott Nelson, Antonio Vasquez-Arroyo and Edward Weisband for their comments and insights. Thank you to Kelsey Butler for her help in formatting this article.

\section{Notes}

1 For an analysis of peacekeeping as the projected image of the power of the Leviathan see Debrix (1999).

2 Disciplinary techniques are applied to institutions through legal reforms as well as to individual public officials through training (see, e.g., efforts to train the police or the judiciary). They are also applied to business (see, e.g., the attempt to promote legislation that prohibits ethnic discrimination in the workplace). For a critical analysis of responsibility as a tool of international governance see Cunliffe (2007).

3 The debate on the legitimacy of humanitarian intervention that developed in the new millennium reflects this reconceptualization of sovereignty around the notion of responsibility. See, for instance, United Nations General Assembly Report of the High-Level Panel on Threats, Challenges and Change, A More Secure World: Our Shared Responsibility, UN Doc. A/59/565 2004 .

4 I have adopted this term for lack of an established terminology.

5 Ernesto Laclau (1996), in his exploration of the uses of the notion of emancipation, argues that both secular and religious emancipatory discourses rely on dichotomic understandings that posit a total externality between the oppressor and the oppressed. For Laclau, the relation between the oppressor and the oppressed is one of undecidability: 'to be oppressed is part of my identity as a subject struggling for emancipation; without the presence of the oppressor my identity would be different' (Laclau 1996: 17). Thus, for Laclau, contemporary social struggles put us face to face with the very possibilities that are opened by our finitude. To reflect this 
conceptualization, Laclau chooses the word 'freedom' instead of emancipation. A debate on the semantics of emancipation, freedom and liberation is beyond the scope of this study. I have chosen to mostly use the term 'liberation' because this is the term of choice of the literature I am critically addressing.

6 However, while for Arendt and Huizinga the struggle is about recognition and rule, for Foucault it involves the contestation of the very rules of the game (Tully 1999).

7 For a critique of Agamben's discussion of sovereignty and power see also Andrew W. Neal (2004). For Neal, Agamben poses the problem of sovereignty in rather apolitical and juridicophilosophical terms, and creates caricatured extremes. In contrast, Foucault engages in a historical critique of sovereignty, in particular sovereignty in its Hobbesian form as the emanation from a single centre of power.

8 Here Prozorov differs from Agamben: while, for Agamben, the sovereign's decision on exception is the basis for the reduction of political life to bare life, for Prozorov the sovereign's decision on exception constitutes a pristine constitutional moment of political life and the 'way out' from the totalizing inscriptions of liberal power.

9 Prozorov criticizes Negri's attempt to achieve emancipation through the rebellious actions of multitudes.

10 For an extensive discussion of the epistemological differences between governmentality studies and sociologies of rule see Rose (1999: 19).

11 Basic Agreement on the Region of Eastern Slavonia, Baranja and Western Sirmium.

12 This note, which was circulated by the UNLO to the Zagreb-based international partners, reconfirmed the continuing validity of the provisions of the Erdut Agreement after the end of peacekeeping.

13 As of July 2001, the Article 11 Commission included, in addition to the Head of the UNLO, the Ambassadors of Austria, Belgium, Canada, Finland, France, Germany, Great Britain, Greece, Italy, Japan, the Netherlands, Norway, Poland, Portugal, The Russian Federation, Spain, Sweden, Switzerland, European Union, the rotating EU Ambassador, the OSCE Head of Mission, the Head of the European Union Military Monitor Mission and the Head of the UNHCR.

14 The author participated in several meetings of the Article 11 Commission. The information provided here has been garnered in this context.

15 Declaration on Educational Certificates (11 March, 1997); Agreement on the Distribution of Principal's Positions (4 August, 1997); Decision on Curriculum Content (4 August, 1997); Declaration on Minority Education Rights (6 August, 1997); Letter of Agreement of the Ministry of Education (7 August, 1997).

16 'Immediate priorities of the Government of Croatia for the coming winter must include the extension of national social welfare into the region to avert grave humanitarian difficulties for vulnerable groups; completion of the reintegration of health facilities and personnel; resolution of the substantial difficulties in the education sector as a whole; improvement of the conditions for return of all displaced persons in conditions of safety, economic security and personal dignity; completion of the establishment of fully functioning local government; and cessation of back-tracking on its commitment to defer conscription for two years for Serbs in the region' (United Nations Security Council 1997b: para 9).

17 These are as follows: Affidavit on the Rights of Public Employees (16-18 December, 1996); Annex to the Affidavit (14 February, 1997); Law on Convalidation (22 September, 1997); Letter of Agreement by the Croatian Highway Administration (21 March, 1997); Letter of Agreement by Croatian State Radio and Television (2 April, 1997); Letter of Agreement by the Croatian Post and Telecommunications Administration (9 May, 1997); Letter of Agreement by the Croatian Water Administration (22 May, 1997); Agreement by the Croatian Pension Fund on Pension Services (29 May, 1997); Letter of Agreement by the Croatian Railways (6 June, 1997); 
Agreement by the Ministry of Health on Regional Health Services (6 June, 1997); Letter of Agreement by the Croatian Electricity Company (22 July, 1997); Letter of Agreement by the Croatian Forestry Commission (26 June, 1997); Declaration on Educational Certificates (11 March, 1997); Agreement on the Distribution of Principals' positions (4 August, 1997); Decision on Curriculum Content (4 August, 1997); Declaration on Minority Education Rights (6 August, 1997); Letter of Agreement by the Ministry of Education (7 August, 1997); Joint Statement on the Reintegration of the Tax Department (4 September, 1997); Joint Statement on Reintegration of the Employment System (11 September, 1997); Joint Statement on Reintegration of the Social Welfare System (11 September, 1997); Agreement on Recognition and Handover of Record Books (25 September, 1997); Memorandum of Understanding on Restructuring the Transitional Police Force (undated); Agreement on the Joint Working Group on Returns (23 April, 1997); Organization of the Joint Council of Municipalities (23 May, 1997); Declaration on Conditions for Judicial Reintegration (19 September, 1997).

18 The author represented the UNLO at this Working Group.

19 Croatia has been a member of the Council of Europe since 1996. On its accession to the Council of Europe, Croatia committed to carry out the Venice Commission's recommendations regarding amendments to the 1991 Constitutional Law on Human Rights and Rights of Minorities. In addition, in accordance with these commitments, international advisers appointed by the Council of Europe participate in the works of the Constitutional Court of Croatia in cases regarding minority rights.

20 The agreement to the SAP by the countries in the region was sealed at the Zagreb Summit, held on 24 November, 2000. The countries concerned were Croatia, Bosnia and Herzegovina, Serbia and Montenegro, FYROM and Albania.

21 'Specifically, these criteria are: - stability of institutions guaranteeing democracy, the rule of law, human rights and respect for and protection of minorities;-the existence of a functioning market economy, as well as the ability to cope with competitive pressures and market forces within the Union; - the ability to take on the obligations of membership, including adherence to the aims of political, economic and monetary union' (Commission of the European Communities 2004).

22 'For the harmonization of the European Union regional policy, the establishment of the degree of regional development of a specific country, as well as for the formulation, implementation and monitoring of regional policy, there is a need to develop a harmonious system of statistical regions, which will allow the collection and processing of comparable data... By introducing the NUTS, Croatia would be a step closer to Europe but also to the formulation, implementation and monitoring of regional policy' (United Nations Development Programme 2003: 20).

23 'Croatia lacks systematic regional statistics. By dividing the territory of the Republic of Croatia into statistical regions it will be possible to establish regional statistics, as well as to harmonize regional data and assure their comparability as a basis for formulation of regional policy. The regions of comparable size (in terms of population size) belong to the same NUTS level, and it is therefore possible to make comparisons and various conclusions regarding different aspects of development of the regions. Only by analyzing the data collected, using a common methodology in regions of the same level is it possible to compare counties, groups of counties, municipalities and cities, calculate certain indicators and monitor effects of regional development measures' (UNDP 2003: 135.).

24 'In the last fifty or so years administrative organization of the territory of the Republic of Croatia has been rather unstable. The division of state territory into regions is questionable still today and the regional policy is becoming barely discernable. There is no system of monitoring statistical data needed for the implementation, control and evaluation of regional policy measures' (UNDP 2003: 133).

25 On 23 January the principals of the international organizations of the JLWG addressed a letter to the Prime Minister in this regard. The motivation for suspension of the activities of the 
Working Group was given as follows: 'We regret the failure of the Croatian side to take advantage of the possibilities offered by the JLWG. Pending renewal of a clear Government commitment to the JLWG along the lines that we have suggested, we therefore do not find it useful to convene other meetings of the JLWG'.

26 Démarche of 27 July, 2001 with the Deputy Minister of Interior, undertaken jointly by the UNLO (represented by the author) and the OSCE, represented by the Head of Mission Ambassador Bernard Poncet.

27 The MOU is listed among the 27 agreements of continuing validity annexed to the SecretaryGeneral's report of 4 December, 1997 S/1997/953. Diverging interpretations between the Croatian Government and the international partners (the OSCE and the Article 11 Commission in particular) with regard to the meaning of proportionality delayed the full implementation of proportional ethnic representation. While the position of the bilateral partners of Croatia and the Zagreb-based international organizations was that only officers in uniform should be included in calculations, the government also counted civilian personnel dealing with administration, cleaning and other types of services.

28 Notwithstanding international pressure, the Ministry of Interior did not make its first priority proportionality of representation in the police force throughout the Croatian territory. For example, the 2003 publication of the public competition for the retraining of 250 attendants as police officers does not include any provision regarding ethnic proportionality. Upon inquiry by the OSCE Police Adviser, the Ministry of Interior indicated that out of these 250 posts, 50 are reserved for females and minorities. However, this information could not be confirmed in any public document (Source: David Hankock, OSCE Police Adviser, OSCE Zagreb, interviewed by the author, OSCE Headquarters on 10 June, 2003).

29 'Amendments to the Law on the Election of Members of Representative Bodies of Local and Regional Self-Government Units' adopted by the Parliament on 11 March, 2003.

30 A writing contest, organized and managed by the author in high schools in Eastern Slavonia, highlighted that youths of Croat and Serb ethnicity still lived separate lives and blamed each other for the war.

\section{References}

Agamben, Giorgio (1998) Homo Sacer: Sovereign Power and Bare Life, Stanford, CA: Stanford University Press.

Arendt, Hannah (ed) (1977) 'What is Freedom?', in Between Past and Future, 143-72, Harmonsworth: Penguin.

Basic Agreement on the Region of Eastern Slavonia, Baranja and Western Sirmium (1995) United States Institute for Peace Library, Peace Agreements Digital Collection: http:// www.usip.org.

Brigg, Morgan (2002) 'Post-development, Foucault and the Colonization Metaphor', Third World Quarterly 23(3): 421-36.

Commission of the European Communities (undated) 'The EU Actions in Support to the Stabilization and Association Process, available at http://europa.eu.int/comm/external_ relations/see/actions/sap.htm (accessed 2 August, 2004).

Commission of the European Communities (2002) 'Croatia: The Stabilization and Association Process (SAP), First Annual Report', Report from the Commission. Brussels, April 4, COM (2002), 163 final.

Commission of the European Communities (2004) 'Croatia: Opinion on the Application of Croatia for Membership of the European Union', Brussels, 20 April, COM(2004)-257 final.

Connolly, William E. (1987) Politics and Ambiguity, Madison: The University of Wisconsin Press. 
Connolly, William E. (2004) 'The Complexity of Sovereignty', in Jenny Edkins, Veronique Pin-Fat and Michael Shapiro, eds, Sovereign Lives: Power in Global Politics, 23-40, New York: Routledge.

Correl, Hans (2001) Note to Mr. Guehenno. Croatia: Status of 'Erdut Agreement' (UN internal document, 21 June).

Cunliffe, Philip (2007) 'Sovereignty and the Politics of Responsibility', in Christopher Bickerton, Philip Cunliffe and Alexander Gourevitch, eds, Politics without Sovrereignty: A Critique of Contemporary International Relations, 39-57, London: UCL Press.

Dean, Mitchell (1999) Governmentality: Power and Rule in Modern Society, London: SAGE.

Debrix, Francois (1999) Re-envisioning Peacekeeping: The United Nations and the Mobilization of Ideology, Minneapolis: University of Minnesota Press.

Edkins, Jenny and Veronique Pin-Fat (2004) 'Life, Power, Resistance', in Jenny Edkins, Veronique Pin-Fat and Michael Shapiro, eds, Sovereign Lives: Power in Global Politics, 1-21, New York: Routledge.

Edkins, Jenny, Veronique Pin-Fat and Michael Shapiro, eds (2004) Sovereign Lives: Power in Global Politics, New York: Routledge.

Foucault, Michel (1975-1976) Society Must be Defended: Lectures at the Collège de France, New York: Picador.

Foucault, Michel (1982) 'The Subject and Power', in Hubert Dreyfus and Paul Rabinow, eds, Michel Foucault Between Structuralism and Hermeneutics, 208-26, Chicago: The University of Chicago Press.

Foucault, Michel (1991a) 'Governmentality', in Graham Burchell, Colin Gordon and Peter Miller, eds, The Foucault Effect: Studies in Governmentality, 87-104, Chicago: The University of Chicago Press.

Foucault, Michel (1991b) 'Questions of Method', in Graham Burchell, Colin Gordon and Peter Miller, eds, The Foucault Effect: Studies in Governmentality, 73-86, Chicago: The University of Chicago Press.

Foucault, Michel (1995) Discipline and Punish: The Birth of the Prison, York: Vintage Books.

Hindess, Barry (1996) Discourses of Power from Hobbes to Foucault, Cambridge, MA: Blackwell.

Huizinga, Johan (1955) Homo Ludens: A Study of the Play Element in Culture, Boston, MA: Beacon Press.

Huysmans, Jef (2004) 'A Foucauldian View on Spill-over: Freedom and Security in the EU', Journal of International Relations and Development 7(3): 294-318.

ICG - International Crisis Group (2002) 'A Half-Hearted Welcome: Refugee Returns to Croatia', Balkans Report No. 138.

Laclau, Ernesto (1996) Emancipation(s), London: Verso.

Larner, Wendy and William Walters, eds (2004a) Global Governmentality: Governing International Spaces, London: Routledge.

Larner, Wendy and William Walters (2004b) 'Globalization as Governmentalization', Alternatives: Global, Local, Political 29(5): 495-514.

Lipshutz, Ronnie and James Rowe (2005) Globalization, Governmentality and Global Politics: Regulation for the Rest of Us? London: Routledge.

Maurer, Bill and Richard Warren Perry, eds (2003) Globalization, Law and Identity, Minneapolis: University of Minnesota Press.

Merlingen, Michael (2006) 'Foucault and World Politics: Promises and Challenges of Extending Governmentality Theory to the European and Beyond', Millennium: Journal of International Studies 35(1): 181-96.

Merlingen, Michael and Rasa Ostrauskauite (2006) European Union Peacebuilding and Policing: Governance and the European Security Defense Policy, London: Routledge.

Ministry of Public Work, Reconstruction and Construction (2003) Return of Displaced Persons and Refugees: Repossession of Property. Zagreb, January, Paper distributed at the Briefing on the 
Progress in the Process of Returns of Refugees 2000-2003 held by the Ministry in Zagreb, Sheraton Hotel, on 3 February, 2003).

Moran, Michael (2003) The British Regulatory State: High Modernism and Hyper-Innovation, Oxford: Oxford University Press.

NATO - North Atlantic Treaty Organization (2004) Membership Action Plan (MAP), available at http://www.nato.int/issues/map/ 2 August, 2004.

Neal, Andrew (2004) 'Cutting off the King's Head: Foucault's Society Must be Defended and the Problem of Sovereignty’, Alternatives, Global, Local Political 29(4): 373-98.

OSCE Mission to Croatia (2004) Status Report No. 15 on Croatia's Progress in Meeting international Commitments since July 2004, 21 November.

OSCE Mission to Croatia (2005) Status Report No. 17 on Croatia's Progress in Meeting International Commitments since July 2004, 10 November.

OSCE Mission to Croatia (2006) Report on Property Repossession, 27 April.

Prozorov, Sergei (2004) 'Three Theses on "Governance" and the Political', Journal of International Relations and Development 7(3): 267-93.

Prozorov, Sergei (2007) Foucault, Freedom, and Sovereignty, Burlington: Ashgate.

Rose, Nikolas (1996) 'Governing Advanced Liberal Democracies', in Andrew Barry, Thomas Osborn and Nikolas Rose, eds, Foucault and Political Reason, 37-64, Chicago: The University of Chicago Press.

Rose, Nikolas (1999) Powers of Freedom: Reframing Political Thought, Cambridge: Cambridge University Press.

Tully, James (1999) 'The Agonic Freedom of Citizens', Economy and Society 28: 161-82.

UNDP - United Nations Development Programme (2003) Human Development Report: Croatia 2002, Zagreb: UNDP Croatia.

United Nations Security Council (1997a) Letter dated 13 January, 1997 from the Government of Croatia addressed to the President of the Security Council, S/1997/27, annex.

United Nations Security Council (1997b) Report of the Secretary-General, S/1997/953 of 4 December.

Walters, Williams and Henrik De Haar (2005) Governing Europe: Discourse, Governmentality and European Integration, London: Routledge.

\section{About the Author}

Laura Zanotti is Associate Professor at the Department of Political Science, Virginia Polytechnic Institute and State University. In 2005-2006 she spent an academic year as a Jean Monnet Fellow at the European University Institute in San Domenico di Fiesole, Italy. Prior to that she worked at the United Nations Department of Peacekeeping Operations. Her research and teaching include critical political and international relations theory, as well as international organization, security, peacekeeping and democratization. She has published articles in Alternatives, International Peacekeeping, as well as in the European University Working Papers Series. 